\title{
EDITORIAL
}

\section{Biosphere Day and Its Needed Fund and Prizes}

$\mathrm{T}^{\mathrm{s}}$ he Biosphere being the circa 30-km-thick sphere encircling our Planet Earth - extending so far up into the atmosphere and down underground as any form of life exists naturally, and hence constituting our entire human and all other known forms of life's sole habitat - our utmost duty is to look after it as the quintessential imperative. For it is this relatively transient and all-too-fragile Biosphere, rather than the rest of the far-moresolid Planet Earth, that is gravely threatened by human population-pressures and profligacy. Consequently we proposed, on 21 September* of last year, before a distinguished gathering assembled for the purpose, that the same day on the calendar annually henceforth be solemnly observed and duly celebrated by all humanity as

\section{Biosphere Day**}

The objective of this proposal and ongoing campaign is to remind those throughout the world who are interested in securing a future for their descendents, or even conceivably for themselves, that our only home and life-support needs chronic safeguarding to continue at all equably. Provided the message is put over effectively, this should in time come to involve everybody everywhere, and give our world as we know and cherish it a much-improved chance of survival. Otherwise it is widely believed that continuing "business as usual' would in time lead to the utmost catastrophe or series of catastrophes and, quite conceivably, result in an end to at least all higher forms of life, with Humankind among the earlier victims.

\section{Major Fund Needed}

To publicize this need effectively will be costly in money and effort. Consequently a major fund is advocated and, for the most productive use of time and energy, much more and greatly improved environmental education. For at present - with relatively few far-sighted exceptions - people tend to be interested only in their own and local surrounding affairs, and not to see matters more widely, let alone globally. Yet the global whole is made up of innumerable component portions, and so it is important that we should all - each and every one of us - bow to far wider interests and play our respective parts, however small, in the context of unselfish holism. For use in encouraging this by appropriate means a major

\section{Biosphere Fund}

will be sought, to which contributions will be warmly welcomed. Donors may rest assured that they will be doing something, however modest, towards halting the decline of environmental conditions on Earth, or at least improving the prospect of doing so. They will also be helping to support the Environmental Movement in a meaningful and - we ardently hope - ultimately effective way.

Whether administered by the Foundation for Environmental Conservation, its affiliated World Council For The Biosphere, or otherwise as a tax-exempt charity, the Biosphere Fund will have the primary objective of encouraging research and other activities that are intended to benefit The Biosphere and hence all humanity both now and in the future. It will also be under the supervision of the Swiss Federal and Geneva Cantonal Governments, which require annual reports and detailed accounts of all substantial receipts and expenditures. - and Biosphere Prize(s)

It is hoped from an early date to be able to make annually at least one major award, preferably to be called

\section{The Biosphere Prize,}

to the winning person or group that is judged to have done the most for The Biosphere through leadership, effective work, or discovery and will be most likely to use such a substantial windfall to do more for that most vital cause. Announcement of the winner or winners of the prize or prizes being made each year on Biosphere Day, should give a useful fillip to the latter in a dignified way and ensure due notice by the world's media, though other ways of promotion will of course be sought.

Thus by various means and to the extent that proves possible, we aspire to awaken humanity to the absolute necessity - if life as we favour it in The Biosphere is to survive - to safeguard our life-support and only natural home. This needs to be done inter alia against such major threats as stratospheric ozone depletion, acidic precipitation, expanding desertification, 'concrete jungles', highways, and other loss of cultivable land, 'greenhouse' warming of climate and concomitant rising of sea-levels, loss of tropical forests and of biodiversity, ever-extending poverty and overcrowding, and above all too many and too greedy and wasteful people - so removing the grave doubts that are currently rife about an equable life for our own and Nature's descendents and meanwhile even for ourselves.

\section{NichOLAS POLUNIN}

\footnotetext{
* This date was chosen because it heralds in the Autumnal Equinox of equal division of night and day in the Northern Hemisphere and reciprocally the Spring Equinox in the Southern Hemisphere - see the strengthened statement of Biosphere Day on the reverse of this page.

** See our 'Declaration of Biosphere Day' (Environmental Conservation, 18[3], p. 199, Autumn 1991, with, on the reverse, a selection of six prior reactions) following an 'Editorial: Rays of Hope for Planet Earth and Even Its Biosphere' (ibid., pp. 193-6) and earlier 'Draft Announcement of Biosphere Day' (idem, 18[2], p. 118, 1991).
} 